Check for updates

Cite this: Nanoscale Adv., 2019, 1, 3056

\title{
Synthesis of ternary sulfide nanomaterials using dithiocarbamate complexes as single source precursors
}

\author{
Anna Roffey, (D) ab Nathan Hollingsworth ${ }^{\mathrm{b}}$ and Graeme Hogarth (D) *a
}

We report the use of cheap, readily accessible and easy to handle di-isobutyl-dithiocarbamate complexes, $\left[\mathrm{M}\left(\mathrm{S}_{2} \mathrm{CN}^{i} \mathrm{Bu}_{2}\right)_{n}\right]$, as single source precursors (SSPs) to ternary sulfides of iron-nickel, iron-copper and nickel-cobalt. Varying decomposition temperature and precursor concentrations has a significant effect on both the phase and size of the nanomaterials, and in some instances meta-stable phases are accessible. Decomposition of $\left[\mathrm{Fe}\left(\mathrm{S}_{2} \mathrm{CN}^{i} \mathrm{Bu}_{2}\right)_{3}\right] /\left[\mathrm{Ni}_{2}\left(\mathrm{~S}_{2} \mathrm{CN}^{i} \mathrm{Bu}_{2}\right)_{2}\right]$ at ca. $210-230{ }^{\circ} \mathrm{C}$ affords metastable $\mathrm{FeNi}_{2} \mathrm{~S}_{4}$ (violarite) nanoparticles, while at higher temperatures the thermodynamic product $\left(\mathrm{Fe}, \mathrm{Ni}_{9} \mathrm{~S}_{8}\right.$ (pentlandite) results. Addition of tetra-isobutyl-thiuram disulfide to the decomposition mixture can significantly affect the nature of the product at any particular temperature-concentration, being attributed to suppression of the intramolecular Fe(III) to Fe(II) reduction. Attempts to replicate this simple approach to ternary metal sulfides of iron-indium and iron-zinc were unsuccessful, mixtures of binary metal sulfides resulting. Oleylamine is non-innocent in these transformations, and we propose that SSP decomposition occurs via primary-secondary backbone amide-exchange with primary dithiocarbamate complexes, $\left[\mathrm{M}\left(\mathrm{S}_{2} \mathrm{CNHoleyl}\right)_{n}\right]$, being the active decomposition precursors.

Received 1st May 2019

Accepted 13th June 2019

DOI: $10.1039 / c 9 n a 00275 h$

rsc.li/nanoscale-advances
Dithiocarbamate complexes $^{\mathbf{1 3}}$ find extensive use as single source precursors (SSPs) towards a range of nanomaterials ${ }^{\mathbf{1 4 - 2 2}}$ their utility stemming from their ease of synthesis, and the ability to tune the solubility, volatility and decomposition properties upon making simple changes to the amine substituents. A further advantage of the dithiocarbamate approach to SSPs is the realisation that this simple ligand forms stable complexes with all the transition metals. ${ }^{12}$ Thus in seeking to develop our work on the catalytic properties of metal-sulfide nanomaterials we sought to prepare a range of ternary sulfide nanomaterials, primarily containing iron but also nickel. To do this we have used a range of simple air-stable di-isobutyldithiocarbamate complexes (Chart 1) and carried out decomposition studies in oleylamine under a range of conditions. This has successfully led to the synthesis of a number of phases of FeNi, FeCu and NiCo sulfides which are described herein, although attempts to prepare FeZn and FeIn sulfides by this method failed.

\section{Results and discussion}

\section{(i) Iron-nickel sulfides}

Ternary iron-nickel sulfide materials can take a number of phases, ${ }^{23}$ most commonly (Fe,Ni) ${ }_{9} \mathrm{~S}_{8}$ (pentlandite, pentlandite structure) and $\mathrm{FeNi}_{2} \mathrm{~S}_{3}$ (violarite, inverse thiospinel structure), although a pyrite type structure $(\mathrm{Fe}, \mathrm{Ni}) \mathrm{S}_{2}$ (bravoite) has also been reported. ${ }^{24}$ There are few examples of the synthesis of nanomaterials of these phases. Bezverkhyy and co-workers 


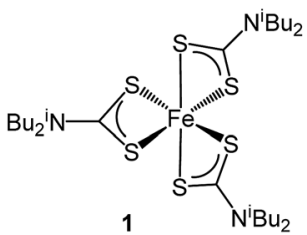

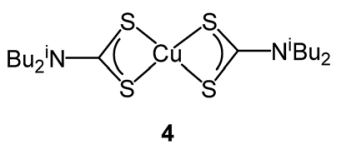

4

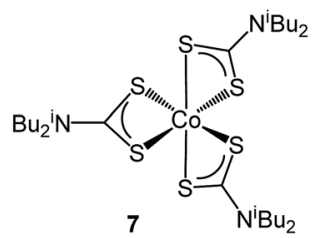

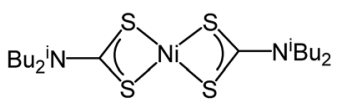

2

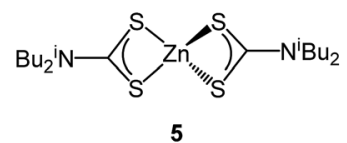

5

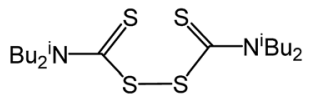

3

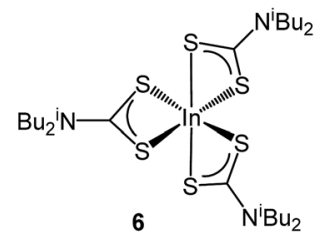

synthesised pentlandite nanoparticles via a multistep process involving pyrolysis in a $\mathrm{H}_{2} \mathrm{~S} / \mathrm{N}_{2}$ atmosphere of a poorly-defined precursor synthesised from $\mathrm{Fe}\left(\mathrm{SO}_{4}\right) \cdot 7 \mathrm{H}_{2} \mathrm{O}$ and $\mathrm{Ni}\left(\mathrm{SO}_{4}\right) \cdot 7 \mathrm{H}_{2} \mathrm{O}^{25}$ and Trávníček reported that a nanoparticulate residue of $\mathrm{Fe}_{5} \mathrm{Ni}_{4} \mathrm{~S}_{8}$ resulted when $\left[\mathrm{Ni}\left(\mathrm{S}_{2} \mathrm{CNBz}^{\mathrm{i}} \mathrm{Pr}\right)_{3}\right]\left[\mathrm{FeCl}_{4}\right]$ was decomposed at $800{ }^{\circ} \mathrm{C}^{26}$ As far as we are aware, there are no reports of either violarite or bravoite being synthesised in the nanoparticle regime.

In our first attempt at preparing ternary iron-nickel sulfide nanomaterials we used $\left[\mathrm{Fe}\left(\mathrm{S}_{2} \mathrm{CN}^{\mathrm{i}} \mathrm{Bu}_{2}\right)_{3}\right](\mathbf{1})$ and $\left[\mathrm{Ni}\left(\mathrm{S}_{2} \mathrm{CN}^{\mathrm{i}} \mathrm{Bu}_{2}\right)_{2}\right]$ (2) as SSPs; decomposition of $2.5 \mathrm{mM}$ quantities of each was carried out in oleylamine at $150,180,230,260$ and $280^{\circ} \mathrm{C}$. Upon warming the oleylamine solution a number of temperaturedependent colour changes were observed, being similar to those previously reported in the decomposition of $\mathbf{1}$ alone, but occurring at ca. $10{ }^{\circ} \mathrm{C}$ higher. ${ }^{12}$ Thus the initially dark brown solution become suddenly clear and pale yellow at $85^{\circ} \mathrm{C}$, then at $90{ }^{\circ} \mathrm{C}$ rapidly went black. Samples were heated to the target temperature and held there for $1 \mathrm{~h}$ after which the generated nanoparticles were isolated as black powders and analysed by PXRD (Fig. 1). At $150{ }^{\circ} \mathrm{C}$ the material generated is mostly amorphous, but by $180{ }^{\circ} \mathrm{C}$ peaks for $\mathrm{FeNi}_{2} \mathrm{~S}_{4}$ begin to emerge and at ca. $230{ }^{\circ} \mathrm{C}$ a mixture of $\mathrm{FeNi}_{2} \mathrm{~S}_{4}, \mathrm{Fe}_{7} \mathrm{~S}_{8}$ and $\alpha$-NiS is seen. Increasing the temperature to $260{ }^{\circ} \mathrm{C}$ sees the emergence of peaks attributed to $(\mathrm{Fe}, \mathrm{Ni})_{9} \mathrm{~S}_{8}$, and at $280{ }^{\circ} \mathrm{C}$ the crystalline phase of the sample appears to be comprised of pure (Fe,Ni) ${ }_{9} \mathrm{~S}_{8}$. This suggests that $\mathrm{FeNi}_{2} \mathrm{~S}_{4}$ (violarite) is metastable, with $(\mathrm{Fe}, \mathrm{Ni})_{9} \mathrm{~S}_{8}$ (pentlandite) being thermodynamically favourable.

The pure (Fe,Ni) ${ }_{9} \mathrm{~S}_{8}$ produced at $280{ }^{\circ} \mathrm{C}$ was analysed by TEM and HRTEM being comprised of roughly hexagonal nanoparticles of $53 \mathrm{~nm}$ (SD $18 \mathrm{~nm}$ ) average diameter (Fig. 2). These are significantly smaller than nanoparticulate pentlandite prepared by Bezverkhyy (Av. $240 \mathrm{~nm}) .{ }^{25}$ HRTEM analysis reveals a d-spacing of $3.55 \AA$ corresponding to the [220] lattice plane (3.57 $\AA$ ).
In recent work we found that decomposition of $\mathbf{1}$ and $\mathbf{2}$ alone were significantly influenced by addition of tetraisobutylthiuram disulfide (3) leading to the increased stability of metastable phases and allowing access to the thiospinel phases $\mathrm{Fe}_{3} \mathrm{~S}_{4}$ and $\mathrm{Ni}_{3} \mathrm{~S}_{4} \cdot{ }^{22}$ For 1 this was related to an intramolecular ligand-metal electron transfer leading to reduction to an $\mathrm{Fe}$ (II) product and extrusion of $\mathbf{3}$, the addition of which moves the equilibrium towards the Fe(III) species. ${ }^{12}$ We thus investigated how the addition of 3 would affect the decomposition of mixtures of $\mathbf{1}$ and 2 . Consequently all reactions were repeated with addition of $c a .4$ equivalents of 3 (i.e. $10 \mathrm{mM} c a .2$ eq. to each precursor). PXRD analysis revealed a similar trend to the samples prepared in the absence of thiuram disulfide but with some notable differences (Fig. 3). Thus, while spectra are similar at low temperatures, at $230{ }^{\circ} \mathrm{C}$ seemingly pure $\mathrm{FeNi}_{2} \mathrm{~S}_{4}$ is

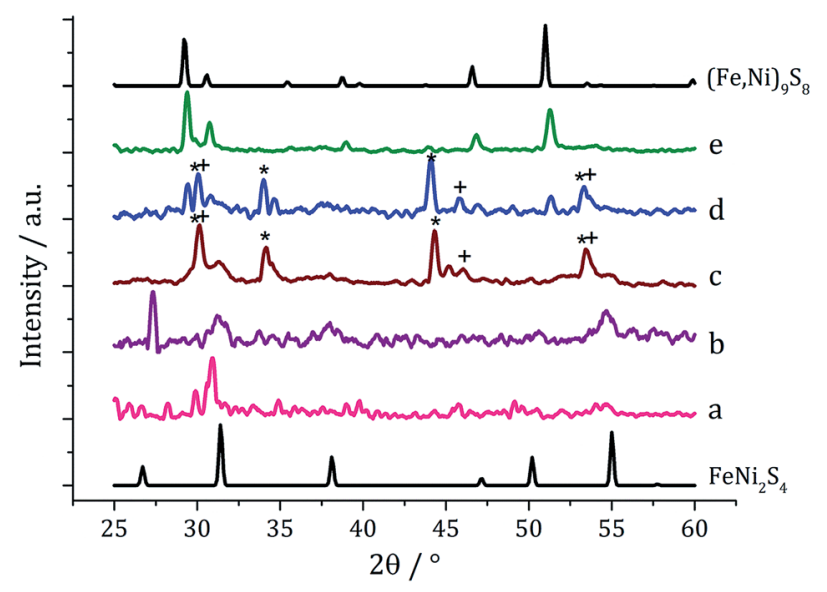

Fig. 1 PXRD patterns for samples prepared from 1 with 2 at (a) $150{ }^{\circ} \mathrm{C}$, (b) $180{ }^{\circ} \mathrm{C}$, (c) $230{ }^{\circ} \mathrm{C}$, (d) $260{ }^{\circ} \mathrm{C}$ and (e) $280{ }^{\circ} \mathrm{C}$, with reference patterns for $\mathrm{FeNi}_{2} \mathrm{~S}_{4}$ (ICDD card no. 47-1740) and (Fe, Ni) ${ }_{9} \mathrm{~S}_{8}$ (ICDD card no. 75-2024). ' $*$ ' indicates $\mathrm{Fe}_{7} \mathrm{~S}_{8}$ peaks and ' + ' indicates $\alpha$-NiS peaks. 

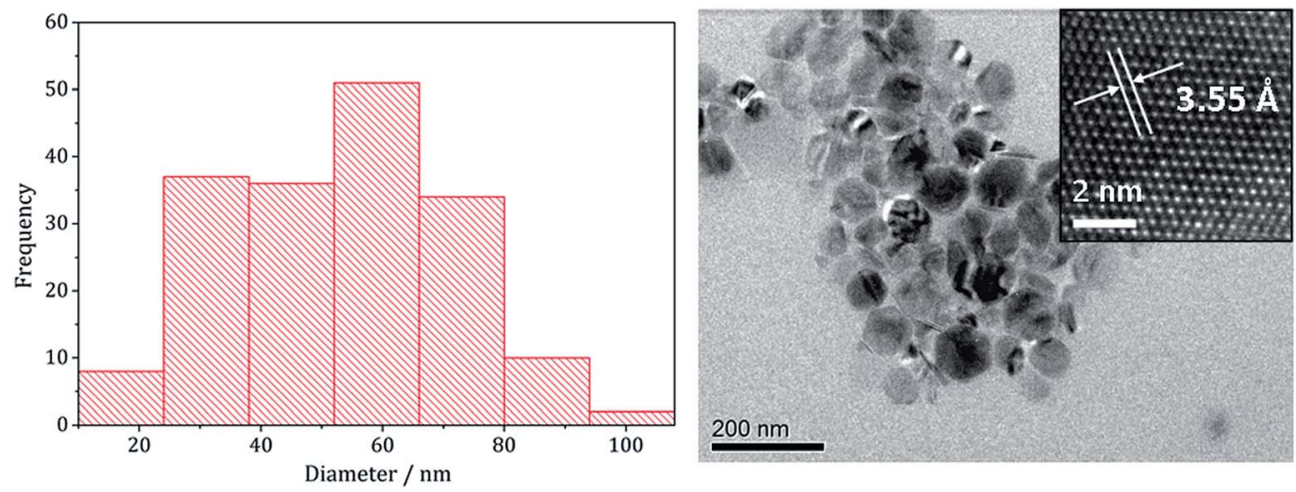

Fig. 2 Particle size histogram (left) and TEM image with HRTEM insert (right) of the $(\mathrm{Fe}, \mathrm{Ni})_{9} \mathrm{~S}_{8}$ sample prepared from 1 with 2 at $280{ }^{\circ} \mathrm{C}$.

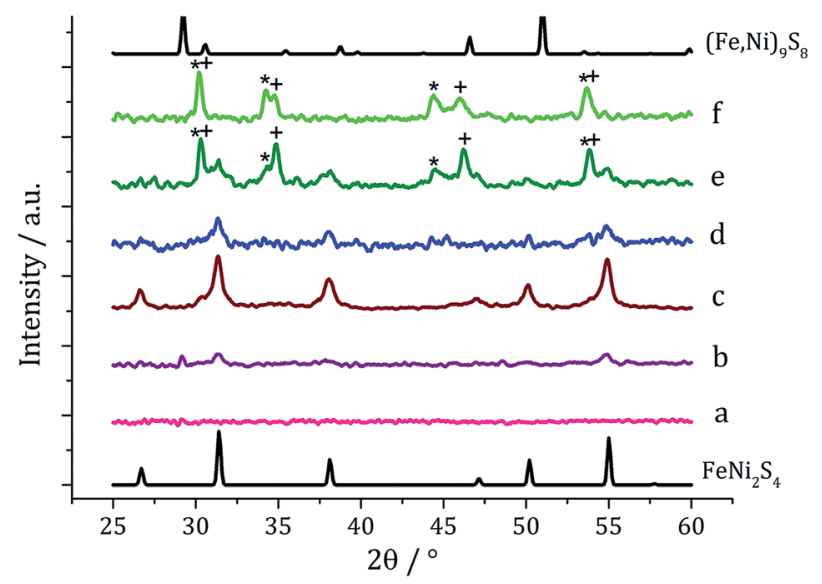

Fig. 3 PXRD patterns for samples prepared from mixtures of 1,2 and 3 at (a) $150^{\circ} \mathrm{C}$, (b) $180^{\circ} \mathrm{C}$, (c) $230^{\circ} \mathrm{C}$, (d) $260^{\circ} \mathrm{C}$, (e) $280^{\circ} \mathrm{C}$, and (f) $300{ }^{\circ} \mathrm{C}$, with reference patterns for $\mathrm{FeNi}_{2} \mathrm{~S}_{4}$ (ICDD card no. 471740) and $(\mathrm{Fe}, \mathrm{Ni})_{9} \mathrm{~S}_{8}$ (ICDD card no. 75-2024). '*' indicates $\mathrm{Fe}_{7} \mathrm{~S}_{8}$ peaks and ' + ' indicates $\alpha$-NiS peaks.

formed, that is without $\mathrm{Fe}_{7} \mathrm{~S}_{8}$ and $\alpha$-NiS impurities seen in the absence of 3 . This indicates that addition of 3 stabilises the thiospinel, $\mathrm{FeNi}_{2} \mathrm{~S}_{4}$, phase possibly preventing formation of binary metal sulfides. At $260{ }^{\circ} \mathrm{C}$ the peaks attributed to $\mathrm{FeNi}_{2} \mathrm{~S}_{4}$ broaden and those of $\mathrm{Fe}_{7} \mathrm{~S}_{8}$ and $\alpha$-NiS begin to appear, while at
$280{ }^{\circ} \mathrm{C}$ the sample is mainly $\mathrm{Fe}_{7} \mathrm{~S}_{8}$ and $\alpha$-NiS, with some $\mathrm{FeNi}_{2} \mathrm{~S}_{4}$ remaining.

To probe whether the thermodynamically stable phase, (Fe, Ni) ${ }_{9} \mathrm{~S}_{8}$, could be accessed in the presence of 3 but at higher temperatures, a decomposition was performed at $300{ }^{\circ} \mathrm{C}$ with addition of only 2 eq. of 3 . PXRD of the resulting material showed the crystalline phase to be a ca. $1: 1$ mix of $\mathrm{Fe}_{7} \mathrm{~S}_{8}$ and $\alpha$ $\mathrm{NiS}$, with neither $\mathrm{FeNi}_{2} \mathrm{~S}_{4}$ or $(\mathrm{Fe}, \mathrm{Ni})_{9} \mathrm{~S}_{8}$ being present. This suggests addition of 3 prevents formation of $(\mathrm{Fe}, \mathrm{Ni})_{9} \mathrm{~S}_{8}$, making binary metal sulfide phases more thermodynamically favourable.

Analysing the $\mathrm{FeNi}_{2} \mathrm{~S}_{4}$ particles produced at $230{ }^{\circ} \mathrm{C}$ by TEM (Fig. 4) showed them to be short rods embedded in hexagonal interlocking sheets with an average diameter of $36.5 \mathrm{~nm}$ (SD 21 $\mathrm{nm}$ ), being slightly smaller than $(\mathrm{Fe}, \mathrm{Ni})_{9} \mathrm{~S}_{4}$ nanoparticles formed in the absence of 3 (average diameter $53.1 \mathrm{~nm}$ ). HRTEM analysis of the nanoparticles reveals $d$-spacings of $3.29 \AA$, corresponding to the [220] lattice plane in $\mathrm{FeNi}_{2} \mathrm{~S}_{4}(3.35 \AA)$.

We next varied precursor concentrations, equimolar amounts of 1 and 2 at 2.5, 5, 10, 20 and $25 \mathrm{mM}$ were decomposed in oleylamine at $230^{\circ} \mathrm{C}$. PXRD analysis reveals a trend in the phase of metal sulfide produced with increasing concentration of precursors (Fig. 5). At $2.5 \mathrm{mM}$ the majority of the crystalline sample corresponds to $\mathrm{Fe}_{7} \mathrm{~S}_{8}$, with some $\mathrm{FeNi}_{2} \mathrm{~S}_{4}$ and $\alpha$-NiS, while at higher concentrations the crystalline phase is predominantly the thiospinel $\mathrm{FeNi}_{2} \mathrm{~S}_{4}$, with some $\alpha$-NiS
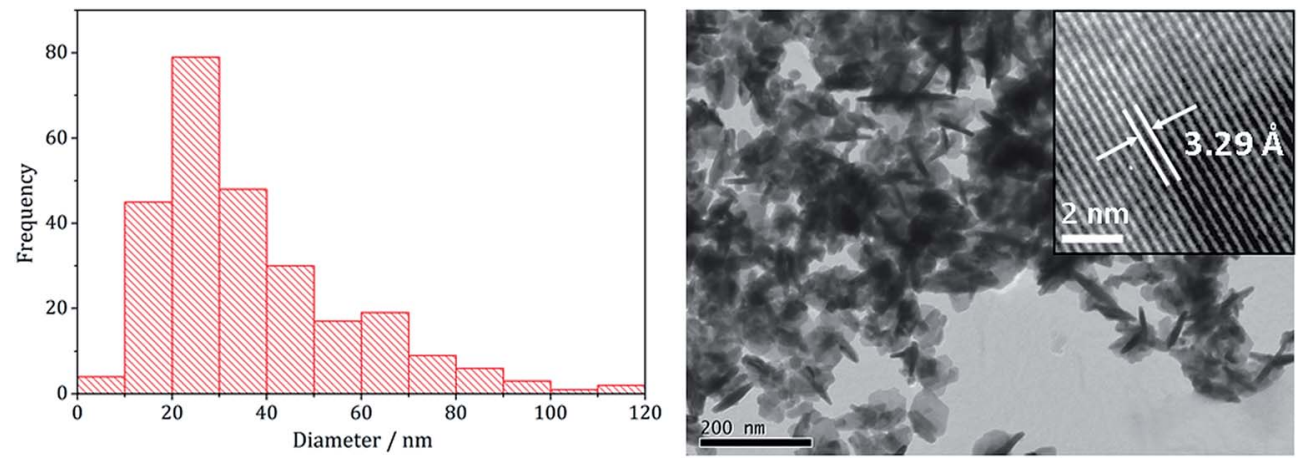

Fig. 4 Particle size histogram (left) and TEM image with HRTEM insert (right) of the $\mathrm{FeNi}_{2} \mathrm{~S}_{4}$ sample prepared from mixtures of $1-3$ at $230{ }^{\circ} \mathrm{C}$. 


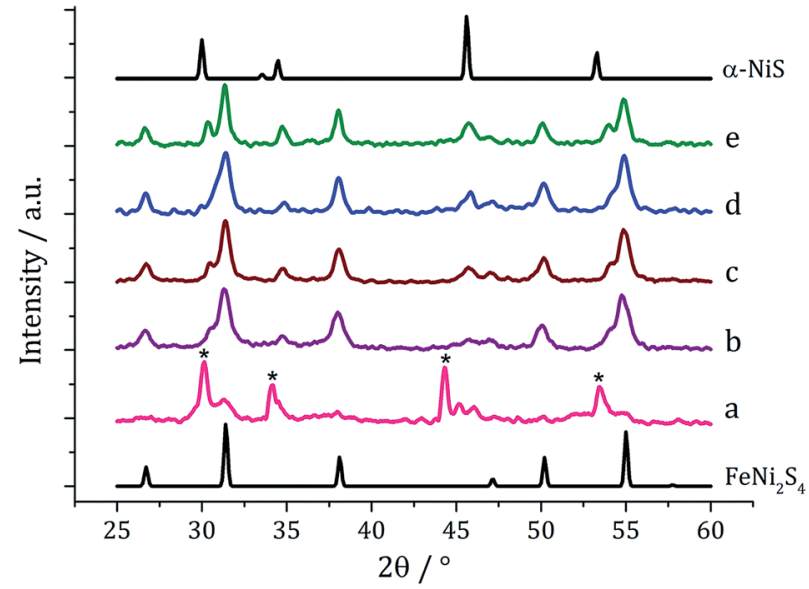

Fig. 5 PXRD patterns for samples prepared from 1-2 at concentrations of (a) $2.5 \mathrm{mM}$, (b) $5 \mathrm{mM}$, (c) $10 \mathrm{mM}$, (d) $20 \mathrm{mM}$ and (e) $25 \mathrm{mM}$, with reference patterns for $\mathrm{FeNi}_{2} \mathrm{~S}_{4}$ (ICDD card no. 47-1740) and $\alpha$-NiS (ICDD card no. 02-1273). '*' indicates peaks for $\mathrm{Fe}_{7} \mathrm{~S}_{8}$.

impurity. This is consistent with the concentration study performed on $\mathbf{1}^{12}$ where at low precursor concentrations $(5 \mathrm{mM})$ $\mathrm{Fe}_{7} \mathrm{~S}_{8}$ was formed, and as the concentration was increased (up to $50 \mathrm{mM}$ ) the phase changed to the thiospinel, $\mathrm{Fe}_{3} \mathrm{~S}_{4}$. When a similar study was performed on 2, changing concentration had no effect on nickel sulfide phase; $\alpha$-Nis being formed at all concentrations.

Experiments were repeated upon addition of four equivalents of 3 and PXRD analysis again shows a concentrationdependent phase change (Fig. 6). At low concentrations pure violarite is formed, but upon increasing the majority of the crystalline material matches the pattern for $(\mathrm{Fe}, \mathrm{Ni}) \mathrm{S}_{2}$ (bravoite, a nickelian pyrite) and for the $1: 2: 3=20: 20: 80 \mathrm{mM}$ sample the pattern matches pure $(\mathrm{Fe}, \mathrm{Ni}) \mathrm{S}_{2}$. Peaks are, broad suggesting that the nanoparticles are small, being consistent with the concentration study on the nickel complex 2 in the presence of $3 .^{22}$ In the ternary system, when the concentration is increased further, additional peaks at slightly higher $2 \theta$ angles appear, indicative of the presence of $\mathrm{FeS}_{2}$ (pyrite). This is interesting since in the binary iron sulfide system, pyrite was not accessible at high concentrations, even after addition of 3. It should also be noted that at higher concentrations, low angle $\left(10-20^{\circ}\right)$ broad peaks are observed, possibly resulting from excess sulfur.

Nanoparticles produced at $20 \mathrm{mM} \mathrm{1-2}$ were analysed by TEM, being approximately spherical and with small crystallite size (average diameter $6.7 \mathrm{~nm}, \mathrm{SD}=1.9 \mathrm{~nm}$ ), as indicated by the broad peaks in the PXRD pattern. They closely resemble $\mathrm{NiS}_{2}$ nanoparticles formed at high concentration of 1 decomposed with $3(1: 3=20: 40 \mathrm{mM})$ which had an average diameter of $4.2 \mathrm{~nm}(\mathrm{SD}=1.3 \mathrm{~nm}) .{ }^{22}$ HRTEM analysis (Fig. 7) of the (Fe,Ni) ${ }_{2}$ nanoparticles reveals $d$-spacings of 3.10 and $2.45 \AA$, which match the [111] and [200] planes of $(\mathrm{Fe}, \mathrm{Ni}) \mathrm{S}_{2}(3.21$ and $2.49 \AA$ respectively).

In summary, products of the mixed iron and nickel ternary sulfide system were found to be highly dependent upon both the decomposition temperature and precursor concentration,

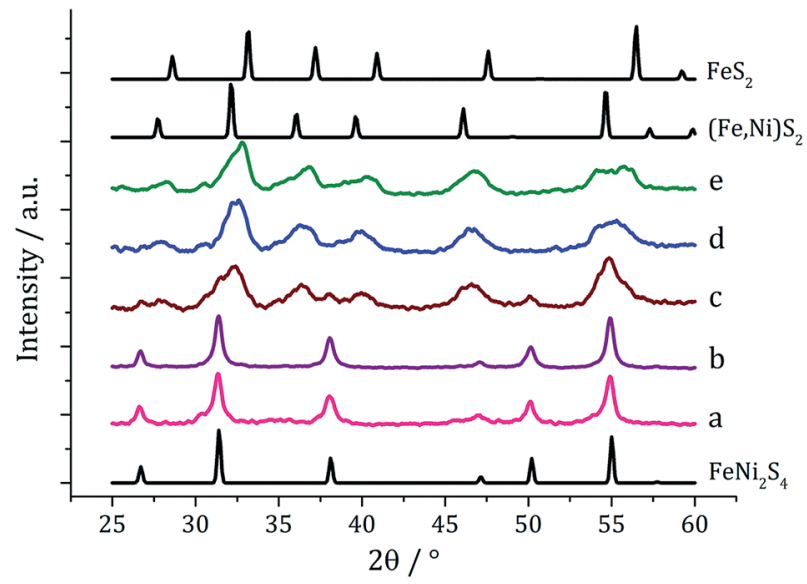

Fig. 6 PXRD patterns for samples prepared from mixtures of 1-3 (1: $1: 2$ ) at concentrations of $1-2$ of (a) $2.5 \mathrm{mM}$, (b) $5 \mathrm{mM}$, (c) $10 \mathrm{mM}$, (d) $20 \mathrm{mM}$ and (e) $25 \mathrm{mM}$, with reference patterns for $\mathrm{FeNi}_{2} \mathrm{~S}_{4}$ (ICDD card no. 47-1740), (Fe,Ni) $\mathrm{S}_{2}$ (ICDD card no. 88-1710) and $\mathrm{FeS}_{2}$ (ICDD card no. 42-1340).

with similarities to both the iron sulfide and nickel sulfide binary systems. The pentlandite phase $(\mathrm{Fe}, \mathrm{Ni})_{9} \mathrm{~S}_{8}$, thiospinel phase $\mathrm{FeNi}_{2} \mathrm{~S}_{4}$ and pyrite phase $(\mathrm{Fe}, \mathrm{Ni}) \mathrm{S}_{2}$ could be selectively produced by varying reaction temperature, precursor concentration and employing the tetra-isobutylthiuram disulfide additive 3 . We believe that this is the first reported synthesis of the latter two phases in nanoparticulate form.

\section{(ii) Iron-copper sulfides}

Copper-iron sulfide has many known phases including $\mathrm{Cu}_{5} \mathrm{FeS}_{4}$ (bornite), $\mathrm{CuFeS}_{2}$ (chalcopyrite) and $\mathrm{CuFe}_{2} \mathrm{~S}_{3}$ (cubanite) ${ }^{27}$ and there are numerous reports on their synthesis, although only a few involving the decomposition of dithiocarbamate complexes. Thus, methods to synthesise nanoparticulate copper-iron sulfides include; solvothermal and microwaveassisted decomposition of metal salts with sulfur sources, colloidal synthesis and laser ablation of bulk $\mathrm{CuFeS}_{2}{ }^{28}$ Two reports have previously detailed the use of dithiocarbamate SSPs for the synthesis of copper-iron sulfide nanoparticles. Gupta utilised a 'hot-injection' method to prepare $\mathrm{CuFeS}_{2}$ nanoparticles of $c a .12 \mathrm{~nm}$ diameter, injecting a mixture of $\left[\mathrm{Cu}\left(\mathrm{S}_{2} \mathrm{CNEt}_{2}\right)_{2}\right]$ and $\left[\mathrm{Fe}\left(\mathrm{S}_{2} \mathrm{CNEt}_{2}\right)_{3}\right]$ in oleylamine/ dichlorobenzene into a solution of sulfur in oleylamine/ trioctylphosphine at $180{ }^{\circ} \mathrm{C},,^{29}$ while Pang and co-workers synthesised $\mathrm{CuFeS}_{2}$ nanoparticles of ca. $6 \mathrm{~nm}$ (ref. 30) upon injecting solution of $\mathrm{NaS}_{2} \mathrm{CNEt}_{2}$ in dodecanethiol into a hot $\left(140{ }^{\circ} \mathrm{C}\right)$ solution of $\mathrm{FeCl}_{3}$ and $\mathrm{CuCl}_{2}$ oleic acid/dodecanethiol; dithiocarbamate complexes presumably being formed in situ. ${ }^{30}$

Following on from our methodology described above, we decomposed equimolar amounts $(2.5 \mathrm{mM})$ of brown $\left[\mathrm{Cu}\left(\mathrm{S}_{2^{-}}\right.\right.$ $\left.\left.\mathrm{CN}^{\mathrm{i}} \mathrm{Bu}_{2}\right)_{2}\right](4)$ and $\left[\mathrm{Fe}\left(\mathrm{S}_{2} \mathrm{CN}^{\mathrm{i}} \mathrm{Bu}_{2}\right)_{3}\right](\mathbf{1})$ in oleylamine at $230{ }^{\circ} \mathrm{C}$. The reaction was then repeated with the addition 4 eq. of thiuram disulfide 3 , and the resulting brown powders were analysed. No discernible colour changes occurred during these reactions, clear purple dispersions resulting in chlorinated 

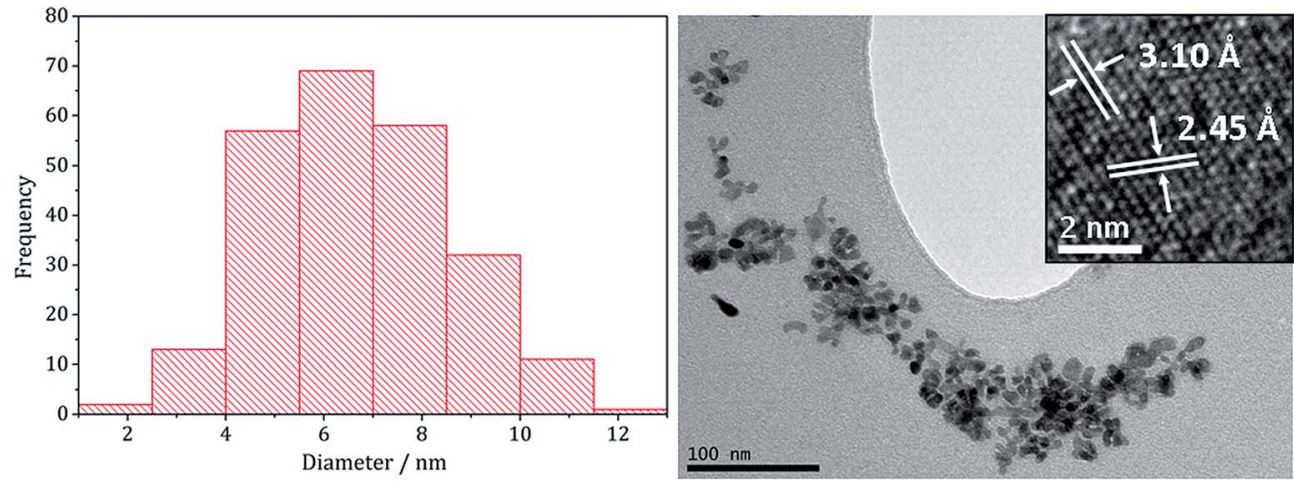

Fig. 7 Particle size histogram (left) and TEM image with HRTEM insert (right) of the (Fe,Ni) $\mathrm{S}_{2}$ sample prepared from 1-3 at concentrations $20: 20: 80 \mathrm{mM}$.

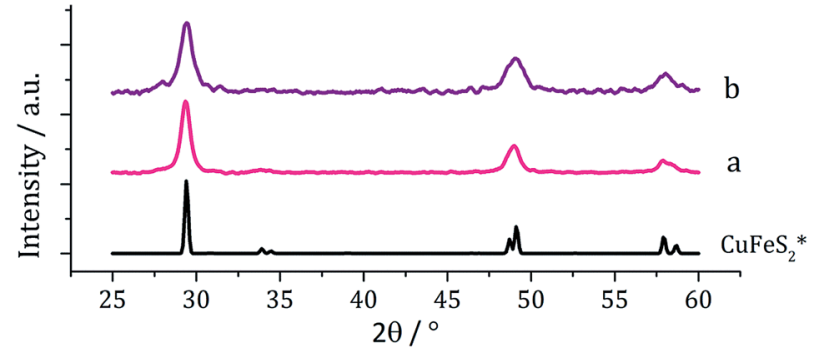

Fig. 8 PXRD patterns for samples prepared from (a) 1 and 4 and (b) 1 and 4 with added 3, with reference pattern for bulk $\mathrm{CuFeS}_{2}$ (ICDD card no. 37-0471).

solvents. PXRD analysis (Fig. 8) showed that the crystalline phase produced in both cases corresponded to $\mathrm{CuFeS}_{2}$ (chalcopyrite). This is in accordance with previous literature. ${ }^{29,30}$ TEM analysis revealed that addition of $3 \mathrm{had}$ little effect on the size or morphology of the nanoparticles, which were roughly spherical (Fig. 9). Average particle diameters were $11 \mathrm{~nm}(\mathrm{SD}=4$ $\mathrm{nm})$ without 3 , and $10 \mathrm{~nm}(\mathrm{SD}=4 \mathrm{~nm})$ with 3 . HRTEM analysis (Fig. 9) revealed a $d$-spacing of $2.99 \AA$, which matches the [112] plane (3.21 $\AA$, $\left.\mathrm{CuFeS}_{2}\right)$.

These results are in accord with those of Gupta and coworker $s^{29}$ who generated similar nanomaterials at $180^{\circ} \mathrm{C}$. Even upon increasing the temperature by $50^{\circ} \mathrm{C}$ we saw no significant change in the nanoparticle size suggesting that during nanoparticle formation the duration of burst nucleation and the number of nucleation sites is not affected by temperature.

\section{(iii) Attempts to prepare iron-zinc sulfides}

There are several known phases of the ternary sulfide of iron and zinc; $(\mathrm{Zn}, \mathrm{Fe}) \mathrm{S}$ wurtzite ( $\{\mathrm{ZnFe}\} \mathrm{S}_{(\mathrm{W})}$, an iron doped wurtzite), $(\mathrm{Zn}, \mathrm{Fe}) \mathrm{S}$ marmatite $\left(\left\{\mathrm{ZnFe} \mathrm{S}_{(\mathrm{S})}\right.\right.$, an iron rich sphalerite) and $\mathrm{ZnFe}_{2} \mathrm{~S}_{4}$, a thiospinel ${ }^{31}$ but few reports on nanoparticulate synthesis and none involving a dithiocarbamate SSP. Feng and co-workers prepared thin films of $(\mathrm{Zn}, \mathrm{Fe}) \mathrm{S}_{(\mathrm{w})}$ by MOCVD at $350{ }^{\circ} \mathrm{C}$ from $\left[\mathrm{Fe}(\mathrm{CO})_{5}\right], \mathrm{Me}_{2} \mathrm{Zn}$ and $\mathrm{H}_{2} \mathrm{~S}^{32}$ and the same material was synthesised in nanoparticulate form upon solvothermal decomposition of $\left[\mathrm{Zn}(\mathrm{Aftscz})_{2}\right]$ and $\left[\mathrm{Zn}(\mathrm{AftsczH})_{2} \mathrm{Cl}_{2}\right](\mathrm{AftsczH}=$ monoacetylferrocene thiosemicarbazole) in ethylene glycol. ${ }^{33}$ Nanoparticles of $(\mathrm{Zn}, \mathrm{Fe}) \mathrm{S}_{(\mathrm{S})}$ have also been synthesised; Chen et al. prepared $\mathrm{Zn}_{0.9} \mathrm{Fe}_{0.1} \mathrm{~S}$ upon annealing nanoparticles produced from a micro-emulsion of $\left[\mathrm{Fe}(\mathrm{CO})_{5}\right],\left[\mathrm{Zn}\left(\mathrm{O}_{2} \mathrm{CCH}_{3}\right)_{2}\right]$ and $\mathrm{CH}_{3}\left(\mathrm{CH}_{2}\right)_{11} \mathrm{OSO}_{3} \mathrm{Na}$ (sodium dodecyl sulphate) in water with added thioacetamide. ${ }^{34}$

We used equimolar amounts $(2.5 \mathrm{mM})$ of $\left[\mathrm{Zn}\left(\mathrm{S}_{2} \mathrm{CN}^{\mathrm{i}} \mathrm{Bu}_{2}\right)_{2}\right](5)$ and $\left[\mathrm{Fe}\left(\mathrm{S}_{2} \mathrm{CN}^{\mathrm{i}} \mathrm{Bu}_{2}\right)_{3}\right](\mathbf{1})$ in oleylamine at $230{ }^{\circ} \mathrm{C}$ in the absence and presence of 4 eq. of thiuram disulfide 3 . As with previous decompositions involving $\mathbf{1}$, dark brown solutions suddenly became clear and pale yellow at $c a .85^{\circ} \mathrm{C}$, and at $100^{\circ} \mathrm{C}$ quickly
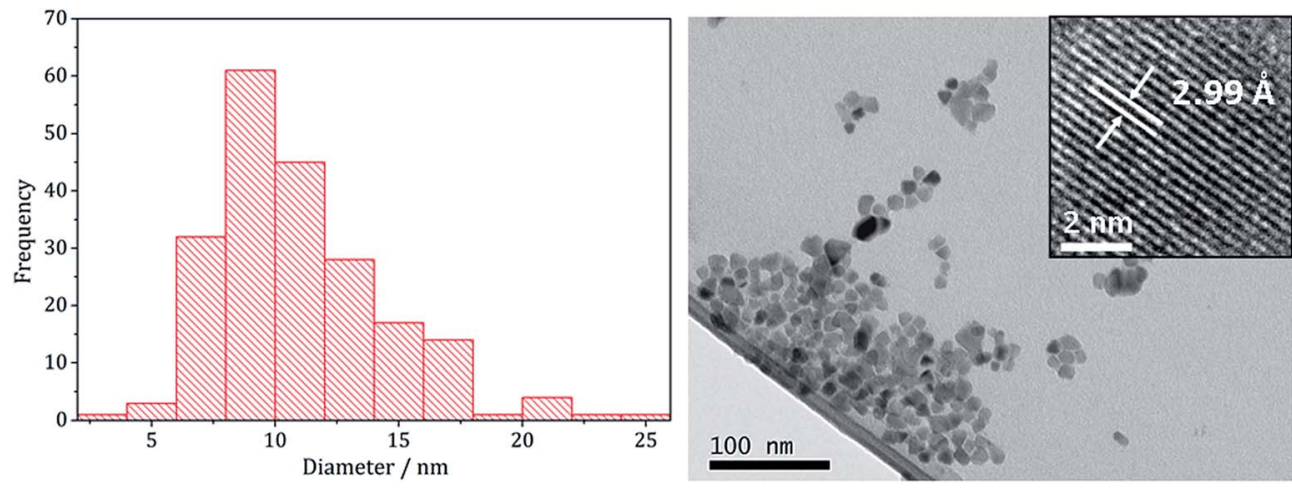

Fig. 9 Particle size histogram (left) and TEM image with HRTEM insert (right) of the sample prepared from 1 and 4. 


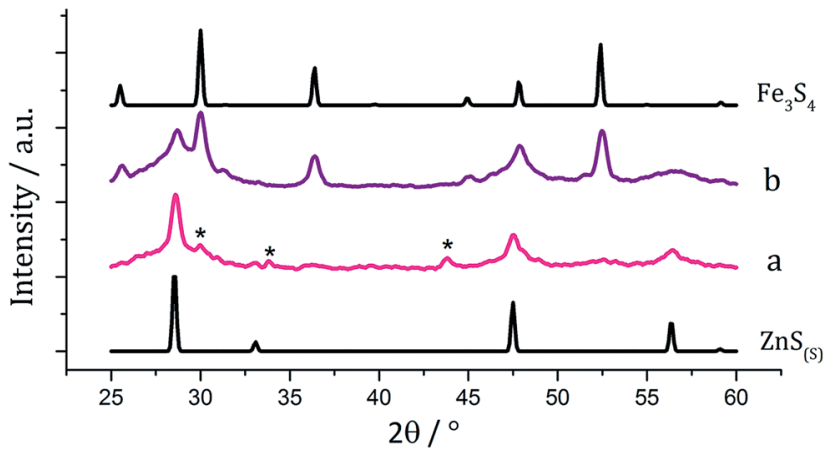

Fig. 10 PXRD patterns for samples prepared from (a) 1 with 5 and (b) 1 with 5 and 3 , with reference patterns for bulk $\mathrm{ZnS}_{(\mathrm{S})}$ (ICDD card no. 772100) and $\mathrm{Fe}_{3} \mathrm{~S}_{4}$ (ICDD card no. 16-0713). ' $*$ ' indicates peaks for $\mathrm{Fe}_{7} \mathrm{~S}_{8}$

turned black. Dark brown powders were isolated but PXRD analysis revealed that the crystalline phase corresponded to a mixture of iron sulfide and zinc sulfide phases (Fig. 10). Interestingly, in both the zinc sulfide phase matched to the pattern for the sphalerite rather than the wurtzite phase. Notably the characteristic peak for $\mathrm{ZnS}_{(\mathrm{W})}$ at $39.8^{\circ} 2 \theta$ is absent. Peaks match well for $\mathrm{ZnS}_{(\mathrm{S})}$, and are not shifted to lower angles, as previously observed for mixed iron and zinc sulfide systems ${ }^{32}$ suggesting that no ternary mixed-metal sulfide has been formed. The reason for this is unclear, but possibly the precursors decompose at quite different temperatures, giving rise to separate nucleation events and forming binary metal sulfide nanoparticles. The sample prepared in the absence of 3 appears to also have peaks for the iron sulfide $\mathrm{Fe}_{7} \mathrm{~S}_{8}$ and the sample prepared with 3 contains peaks which match well to $\mathrm{Fe}_{3} \mathrm{~S}_{4}$, the thiospinel phase of iron sulfide. This is consistent with previous results reported on the iron sulfide binary phase system.

TEM images support the PXRD analysis, clearly showing a two phase system (Fig. 11). Samples comprised large hexagonal particles (average diameter $32 \mathrm{~nm}$, SD $16 \mathrm{~nm}$ ) which resemble the iron sulfide phases observed in the binary system, and thin nanowires (length $=16 \mathrm{~nm}, \mathrm{SD} 15 \mathrm{~nm}$, width $=2.9 \mathrm{~nm}$, SD $0.8 \mathrm{~nm}$ ) resembling zinc sulfide material produced in the binary system.

\section{(iv) Attempts to prepare iron-indium sulfides}

There have been few reported syntheses of nanoparticulate FeIn ${ }_{2} \mathrm{~S}_{4}$, and none using solvothermal methods. Related to this work, Wu et al. recently synthesised $\mathrm{FeIn}_{2} \mathrm{~S}_{4}$ microspheres using an indium dithiocarbamate precursor..$^{35}$ Equimolar amounts (2.5 mM) of pale yellow $\left[\operatorname{In}\left(\mathrm{S}_{2} \mathrm{CN}^{\mathrm{i}} \mathrm{Bu}_{2}\right)_{3}\right](6)$ and dark brown

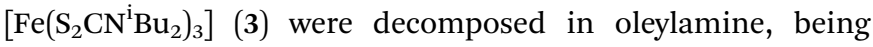
repeated upon addition of $\mathbf{3}$, and the resulting brown powders were analysed. PXRD patterns (Fig. 12) did not match that of the mixed iron indium sulfide, $\mathrm{FeIn}_{2} \mathrm{~S}_{4}$, being broad and indicative of low crystallinity. Peaks for $\mathrm{Fe}_{3} \mathrm{~S}_{4}$ were detectable in both, as well as for $\beta$ - $\operatorname{In}_{2} \mathrm{~S}_{3}$ in the sample prepared with added 3 . As with the iron-zinc sulfide chemistry ternary mixed-metal sulfides were absent. Interestingly, unlike the iron zinc sulfide samples, peaks for pyrrhotite are not observed in the sample prepared without 3, but peaks matching $\mathrm{Fe}_{3} \mathrm{~S}_{4}$ are seen in both. This might suggest that the presence of the indium precursor 6 or indium sulfide product $\beta$ - $\operatorname{In}_{2} S_{3}$ helps to stabilise the iron sulfide thiospinel.

\section{(v) Nickel-cobalt sulfides}

Although the focus of our work with ternary chalcogenides is on mixed-metal iron sulfides, many other combinations of mixedmetal sulfide materials are possible. The nickel-cobalt sulfide system has several possible phases including; $\mathrm{NiCo}_{8} \mathrm{~S}_{8}$ (pentlandite structure), $\mathrm{NiCo}_{2} \mathrm{~S}_{4}$ and $\mathrm{CoNi}_{2} \mathrm{Co}_{4}$ (both thiospinel structure). Nanoparticles of $\mathrm{NiCo}_{8} \mathrm{~S}_{8}$ have been synthesised by Bezverkhyy et al. in a two-step process; firstly $\mathrm{Co}\left(\mathrm{NO}_{3}\right)_{2}$ and $\mathrm{Ni}\left(\mathrm{NO}_{3}\right)_{2}$ were reacted with $\mathrm{Na}_{2} \mathrm{~S}$ in water and then the dried precipitate was heated with $\mathrm{H}_{2} \mathrm{~S} / \mathrm{H}_{2}$ for $3 \mathrm{~h}$ at $300{ }^{\circ} \mathrm{C} .{ }^{25}$ Urchinlike nanostructures of $\mathrm{NiCo}_{2} \mathrm{~S}_{4}$ were synthesised by Jiang and co-workers in a two-step process involving the hydrothermal decomposition of $\mathrm{NiCl}_{2}$ and $\mathrm{CoCl}_{2}$ with urea in an autoclave at $140{ }^{\circ} \mathrm{C}$, followed by a further reaction with $\mathrm{Na}_{2} \mathrm{~S}$ at $160{ }^{\circ} \mathrm{C}$ (ref. 36) and nanoparticles of $\mathrm{CoNi}_{2} \mathrm{~S}_{4}$ were formed in an autoclave by Pang et al., from the slow $(24 \mathrm{~h})$ decomposition of $\left[\mathrm{Co}\left(\mathrm{O}_{2}-\right.\right.$ $\left.\mathrm{CMe})_{2}\right]$ and $\left[\mathrm{Ni}\left(\mathrm{O}_{2} \mathrm{CMe}\right)_{2}\right]$ mixtures with sulfur dissolved in an oleylamine/anisole mixture. ${ }^{37}$

Equimolar amounts $(2.5 \mathrm{mM})$ of $\left[\mathrm{Ni}\left(\mathrm{S}_{2} \mathrm{CN}^{\mathrm{i}} \mathrm{Bu}_{2}\right)_{2}\right](2)$ and $\left[\mathrm{Co}\left(\mathrm{S}_{2} \mathrm{CN}^{\mathrm{i}} \mathrm{Bu}_{2}\right)_{3}\right](7)$ were decomposed in oleylamine at $230{ }^{\circ} \mathrm{C}$,

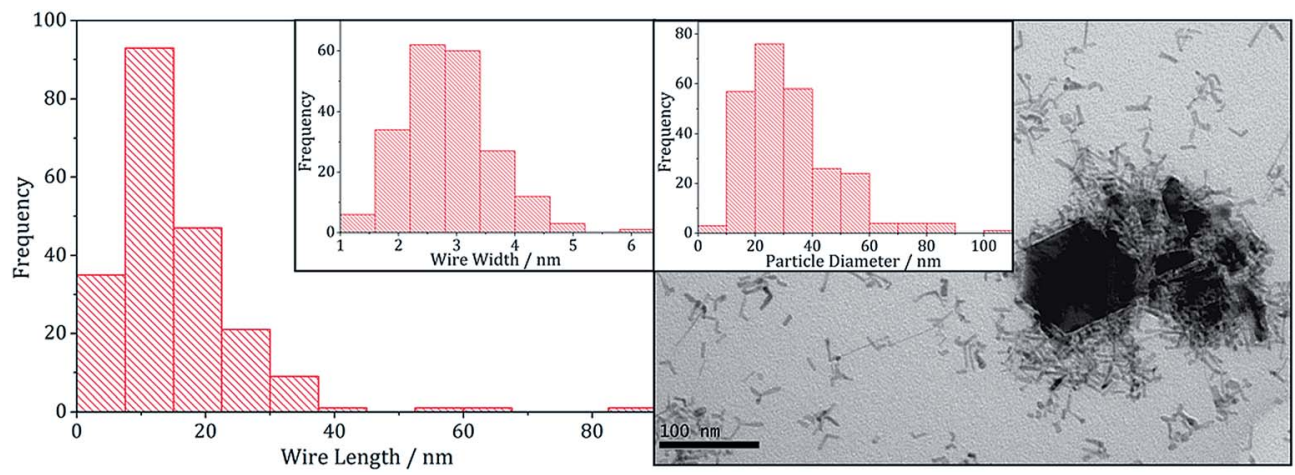

Fig. 11 Wire-length histogram with wire-width histogram insert (left) and TEM image with particle diameter histogram insert (right), of the sample prepared from 1 with 5 . 


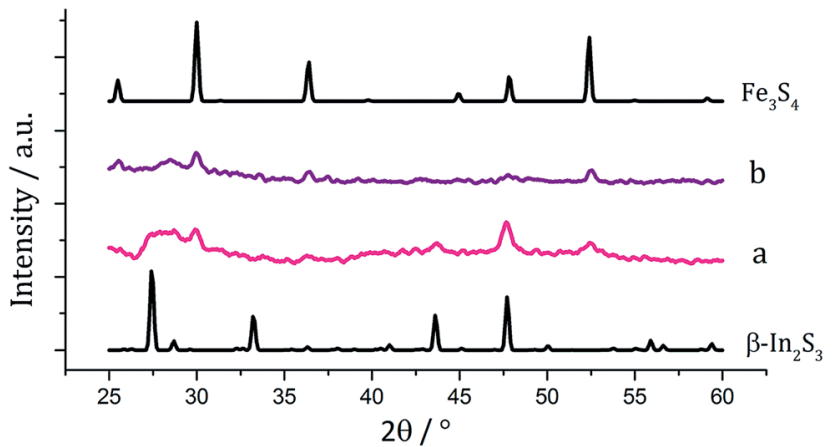

Fig. 12 PXRD patterns for samples prepared from (a) 1 with 6, (b) 1 with 6 and 3, with reference patterns for $\beta-\ln _{2} S_{3}$ (ICDD card no. 25-0390) and $\mathrm{Fe}_{3} \mathrm{~S}_{4}$ (ICDD card no. 16-0713).

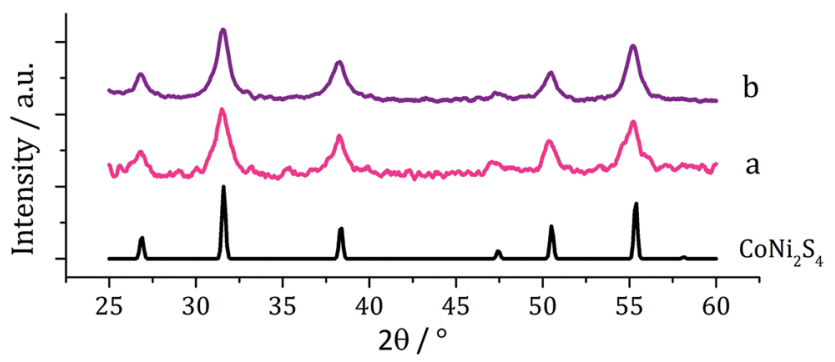

Fig. 13 PXRD patterns for samples prepared from (a) 2 with 7 and (b) 2 with 7 and 3 , with reference pattern for bulk $\mathrm{CoNi}_{2} \mathrm{~S}_{4}$ (ICDD card no. 22-0334).

being repeated upon addition of thiuram disulfide 3 , and the resulting brown powders analysed. PXRD analysis (Fig. 13) revealed no significant shift in peaks between the two samples, indicating that $\mathbf{3}$ has no observable effect on the phase of ternary sulfide produced. In addition, to elucidate whether the nickel or cobalt rich thiospinel structures had been formed $\left(\mathrm{CoNi}_{2} \mathrm{~S}_{4}\right.$ or $\mathrm{NiCo}_{2} \mathrm{~S}_{4}$ respectively) both samples were analysed by energy-dispersive X-ray spectroscopy (EDX) and found to have atomic compositions of cobalt, nickel and sulfur of $1.76: 1.60: 4$ and $1.52: 1.32: 4$, respectively. Although the ratios of metal to sulfur vary slightly, they remain approximately
1.1 : $1 \mathrm{Co}: \mathrm{Ni}$, indicating an intermediate $(\mathrm{Ni}, \mathrm{Co})_{3} \mathrm{~S}_{4}$ phase. The difference between the PXRD patterns for $\mathrm{CoNi}_{2} \mathrm{~S}_{4}$ and $\mathrm{NiCo}_{2} \mathrm{~S}_{4}$ is small; nickel and cobalt having very similar ionic radii and electronegativity, and the patterns obtained for the samples synthesised here closely match both.

TEM analysis revealed the addition 3 also had little effect on the size or morphology of the nanoparticles formed, which were roughly spherical (Fig. 14). The average particle diameters were $10 \mathrm{~nm}(\mathrm{SD}=5 \mathrm{~nm})$ for the sample prepared without 3 , and $10 \mathrm{~nm}(\mathrm{SD}=4 \mathrm{~nm})$ with 3 . Nanoparticles of $\mathrm{CoNi}_{2} \mathrm{~S}_{4}$ previously reported by Pang et al. ${ }^{37}$ were reported to have 'quasi-spherical' morphology with an average diameter of approximately 8$15 \mathrm{~nm}$, similar to those produced in the current study. HRTEM analysis (Fig. 13) of the current $(\mathrm{Ni}, \mathrm{Co})_{3} \mathrm{~S}_{4}$ nanoparticles reveals a $d$-spacing of $2.67 \AA$, which matches the [222] plane $(2.72 \AA$, $\left.\mathrm{CoNi}_{2} \mathrm{~S}_{4}\right)$.

\section{Summary and conclusions}

Nanomaterials of iron-nickel sulfide, iron-copper sulfide and nickel-cobalt sulfide were successfully prepared via the decomposition of mixtures of simple metal-dithiocarbamate complexes in oleylamine, and for iron-nickel mixtures, various sulfide phases were accessible upon varying decomposition conditions. In contrast, attempts to synthesise iron-zinc sulfide and iron-indium sulfide via this method were unsuccessful, producing only binary metal sulfides. This may be due to the precursor complexes decomposing at different temperatures, although this has not been fully established. We have previously shown that $\left[\mathrm{Fe}\left(\mathrm{S}_{2} \mathrm{CN}^{\mathrm{i}} \mathrm{Bu}_{2}\right)_{3}\right](\mathbf{1})$ undergoes an intramolecular electron-transfer process at $c a .80{ }^{\circ} \mathrm{C}$ in oleylamine to generate $\left[\mathrm{Fe}\left(\mathrm{S}_{2} \mathrm{CN}^{\mathrm{i}} \mathrm{Bu}_{2}\right)_{2}\right]$ and thiuram disulfide $\left(\mathrm{S}_{2} \mathrm{CN}^{\mathrm{i}} \mathrm{Bu}_{2}\right)_{2}$ (3). ${ }^{12}$ This also occurs during decompositions carried out here as shown by the sudden colour change from brown to yellow at $c a .80-90{ }^{\circ} \mathrm{C}$. Thus the decomposition mixtures contain an Fe(II) and not an $\mathrm{Fe}(\mathrm{III})$ dithiocarbamate complex. Consistent with this supposition, addition of 3 to the decomposition mixture has a significant effect on the precise nature of the nanomaterials formed. We have also previously shown that decomposition of $\left[\mathrm{Ni}\left(\mathrm{S}_{2}\right.\right.$ $\left.\left.\mathrm{CN}^{\mathrm{i}} \mathrm{Bu}_{2}\right)_{2}\right](2)$ in oleylamine occurs via an initial amide-exchange process to generate the primary amine derivative
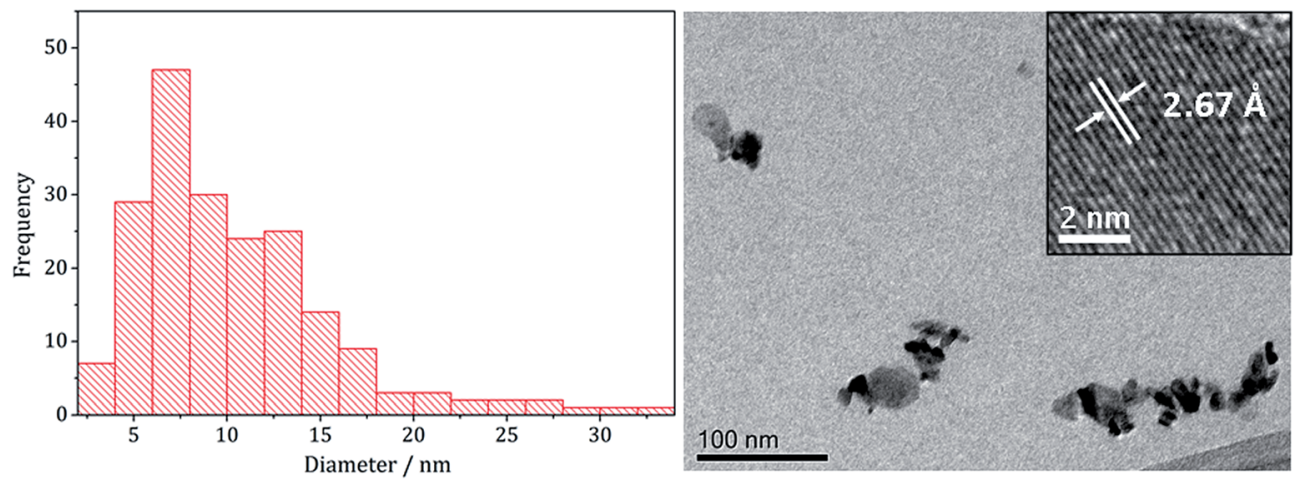

Fig. 14 Particle size histogram (left) and TEM image with HRTEM insert (right) of the $(\mathrm{Ni}, \mathrm{Co})_{3} \mathrm{~S}_{4}$ sample prepared from 2 with 7 and 3. 
$\left[\mathrm{Ni}\left(\mathrm{S}_{2} \mathrm{CNHoleyl}\right)_{2}\right]^{21,22}$ and we have evidence that $\left[\mathrm{Fe}\left(\mathrm{S}_{2} \mathrm{CN}^{\mathrm{i}} \mathrm{Bu}_{2}\right)_{2}\right]$ behaves in the same way. ${ }^{12}$ Thus, while it appears that ironnickel sulfides result from decomposition of $\left[\mathrm{Fe}\left(\mathrm{S}_{2} \mathrm{CN}^{\mathrm{i}} \mathrm{Bu}_{2}\right)_{3}\right](\mathbf{1})$ and $\left[\mathrm{Ni}\left(\mathrm{S}_{2} \mathrm{CN}^{\mathrm{i}} \mathrm{Bu}_{2}\right)_{2}\right](2)$, most likely it is $\left[\mathrm{Ni}\left(\mathrm{S}_{2} \mathrm{CNHoleyl}\right)_{2}\right]$ and $\left[\mathrm{Fe}\left(\mathrm{S}_{2} \mathrm{CNHoleyl}\right)_{2}\right]$ that are actually decomposing via extrusion of oleylNCS. We have less information about the precise nature of 4-7 in oleylamine but cannot rule out similar amideexchange reactions being important. Hence, a general comment about the decomposition of dithiocarbamate SSPs in oleylamine (and other amines) is that, while changes to the alkyl-substituents may appear to lead to different nanomaterial sizes and shapes, this is most likely related to the rate of the amide-exchange reaction rather than the relative strengths of the C-S bonds that are cleaved. This may account for the failed attempts to prepare iron-zinc and iron-indium sulfides, in which we obtained only mixtures of binary sulfides. Thus if amide-exchange (and subsequent decomposition) is much faster for $\left[\mathrm{Fe}\left(\mathrm{S}_{2} \mathrm{CN}^{\mathrm{i}} \mathrm{Bu}_{2}\right)_{2}\right]$ than either $\left[\mathrm{Zn}\left(\mathrm{S}_{2} \mathrm{CN}^{\mathrm{i}} \mathrm{Bu}_{2}\right)_{2}\right]$ or $\left[\mathrm{In}\left(\mathrm{S}_{2}{ }^{-}\right.\right.$ $\left.\left.\mathrm{CN}^{\mathrm{i}} \mathrm{Bu}_{2}\right)_{3}\right]$ then it is easy to see how iron-sulfides would be generated first followed by a slower process to afford zinc or indium sulfide. Consequently we are focusing our current efforts on the synthesis (and subsequent decomposition) of primary-amine dithiocarbamate derivatives, $\left[\mathrm{M}\left(\mathrm{S}_{2} \mathrm{CNHR}\right)_{n}\right]$, since this should allow for far better control over the decomposition process (e.g. lower temperatures, non-amine solvents etc.) potentially providing access to a wider range of binary and ternary metal sulfide nanomaterials.

\section{Experimental section}

\section{General procedures}

Unless otherwise stated, manipulations were performed under a dry, oxygen-free dinitrogen atmosphere using standard Schlenk techniques or in a MBRAUN Unilab glovebox. All solvents used were stored in alumina columns and dried with anhydrous engineering equipment, such that the water concentration was 5-10 ppm. All other reagents were procured commercially from Aldrich and used without further purification.

\section{Physical measurements}

${ }^{1} \mathrm{H}$ and ${ }^{13} \mathrm{C}\left\{{ }^{1} \mathrm{H}\right\}$ NMR spectra were obtained on either a Bruker Avance III 400 or Avance 600 spectrometers. All spectra were recorded using $\mathrm{CDCl}_{3}$ which was dried and degassed over molecular sieves prior to use; ${ }^{1} \mathrm{H}$ and ${ }^{13} \mathrm{C}\left\{{ }^{1} \mathrm{H}\right\}$ chemical shifts are reported relative to $\mathrm{SiMe}_{4}$. Mass spectra were obtained using either Micromass 70-SE spectrometer using Electron Ionisation (EI) or a Thermo Finnigan MAT900xp spectrometer using Fast Atom Bombardment (FAB) ionisation. Elemental analysis was carried using Elemental Analyser (CE-440) (Exeter Analytical Inc). PXRD were measured on a Bruker AXS D4 diffractometer using $\mathrm{CuKa} \alpha_{1}$ radiation, patterns obtained being compared to database standards. For TEM characterisation a $4 \mu \mathrm{l}$ droplet of nanoparticle suspension $\left(\mathrm{CHCl}_{3}\right)$ was placed on a holey carboncoated copper TEM grid and allowed to evaporate in air under ambient laboratory conditions for several minutes. TEM images were obtained using a JEOL-1010 microscope at $100 \mathrm{kV}$ equipped with a Gatan digital camera. HRTEM measurements were collected using a Jeol 2100 (high resolution) TEM with a $\mathrm{LaB}_{6}$ source operating at an acceleration voltage of $200 \mathrm{kv}$. Micrographs were taken on a Gatan Orius Charge-coupled device (CCD).

\section{Synthesis and characterisation of molecular precursors}

$\mathbf{N a}\left[\mathbf{S}_{2} \mathbf{C N}^{\mathrm{i}} \mathbf{B u}_{2}\right] \cdot{ }^{22} \mathrm{Bu}_{2} \mathrm{NH}(5.24 \mathrm{~mL}, 30 \mathrm{mmol})$ was added to $\mathrm{NaOH}(1.20 \mathrm{~g}, 30 \mathrm{mmol})$ in water $(50 \mathrm{~mL})$. To this mixture $\mathrm{CS}_{2}$ $(1.80 \mathrm{~mL}, 30 \mathrm{mmol})$ was added dropwise over $10 \mathrm{~min}$ and the mixture stirred for $1 \mathrm{~h}$. The dithiocarbamate salt was then used in situ adding various equivalents to the respective metal salts being dependent upon the stoichiometry of the product.

$\left[\mathbf{F e}\left(\mathbf{S}_{2} \mathbf{C N}^{\mathrm{i}} \mathbf{B u}_{2}\right)_{3}\right](\mathbf{1}){ }^{38}$ A solution of $\mathrm{FeCl}_{3}(1.62 \mathrm{~g}, 10 \mathrm{mmol})$ in water $(50 \mathrm{~mL})$ was added dropwise over $5 \mathrm{~min}$, whereupon a black precipitate formed. This mixture was vigorously stirred for $2 \mathrm{~h}$, filtered, washed with water $(3 \times 30 \mathrm{~mL})$ and evaporated to dryness. The resulting black powder was dissolved in $100 \mathrm{~mL}$ of $\mathrm{CH}_{2} \mathrm{Cl}_{2}$ and stirred with magnesium sulphate for $30 \mathrm{~min}$, after which the mixture was filtered and the filtrate dried. Yield $5.55 \mathrm{~g}, 83 \%$. Anal. Calc. for $\mathrm{C}_{27} \mathrm{H}_{54} \mathrm{~N}_{3} \mathrm{~S}_{6} \mathrm{Fe}: \mathrm{C}, 48.48 ; \mathrm{H}, 8.14 ; \mathrm{N}$, 6.23. Found: C, 48.52; H, 8.26; N, 6.23. MS: $m / z 669\left[\mathrm{M}^{+}\right], 464\left[\mathrm{M}^{+}\right.$ $-\mathrm{C}_{9} \mathrm{H}_{18} \mathrm{NS}_{2}$ ]. IR $\left(\nu_{\max } \mathrm{cm}^{-1}\right): 1482(\mathrm{~s})[\mathrm{N}=\mathrm{C}], 992(\mathrm{~s}), 1244(\mathrm{~s})$ $[\mathrm{C}=\mathrm{S}], 1145(\mathrm{~s})\left[\mathrm{C}_{2} \mathrm{~N}\right]$.

$\left[\mathbf{N i}\left(\mathbf{S}_{2} \mathbf{C N}^{\mathrm{i}} \mathbf{B u}_{2}\right)_{2}\right](2) .{ }^{22}$ A solution of $\mathrm{NiCl}_{2} \cdot 6 \mathrm{H}_{2} \mathrm{O}(2.38 \mathrm{~g}, 10$ $\mathrm{mmol})$ in water $(50 \mathrm{~mL})$ was added dropwise over $5 \mathrm{~min}$, whereupon a green precipitate formed. This mixture was vigorously stirred for $2 \mathrm{~h}$, filtered, washed with water $(3 \times 30$ $\mathrm{mL}$ ) and evaporated to dryness. The resulting green powder was dissolved in $100 \mathrm{~mL}$ of $\mathrm{CH}_{2} \mathrm{Cl}_{2}$ and stirred with magnesium sulphate for $30 \mathrm{~min}$, after which the mixture was filtered and the filtrate dried. Yield $3.97 \mathrm{~g}, 85 \%$. Anal. Calc. for $\mathrm{C}_{18} \mathrm{H}_{36} \mathrm{~N}_{2} \mathrm{~S}_{4} \mathrm{Ni}$ : C, 46.25; H, 7.76; N, 5.99. Found: C, 46.23; H, 7.81; N, 6.03. ${ }^{1} \mathrm{H}$ NMR $\delta / p p m\left(\mathrm{CDCl}_{3}\right): 0.91\left(\mathrm{~d}, J=6.6 \mathrm{~Hz}, 24 \mathrm{H}, \mathrm{CH}_{3}\right), 2.17(\mathrm{~m}, J=$ $6.8 \mathrm{~Hz}, 4 \mathrm{H}, \mathrm{CH}), 3.40\left(\mathrm{~d}, J=7.7 \mathrm{~Hz}, 8 \mathrm{H}, \mathrm{CH}_{2}\right) .{ }^{13} \mathrm{C}\left\{{ }^{1} \mathrm{H}\right\}$ NMR $\delta /$ ppm (CDCl $)$ : $20.1\left(\mathrm{CH}_{3}\right), 27.0(\mathrm{CH}), 56.3\left(\mathrm{CH}_{2}\right), 208.4\left(\mathrm{CS}_{2}\right)$. MS: $\mathrm{m} / \mathrm{z} 467\left[\mathrm{M}^{+}\right], 171\left[\mathrm{~S}_{2} \mathrm{CN}^{\mathrm{I}} \mathrm{Bu}_{2}\right] . \mathrm{IR}\left(\nu_{\max } \mathrm{cm}^{-1}\right): 1508(\mathrm{~s})[\mathrm{N}=\mathrm{C}]$, $981(\mathrm{~s})[\mathrm{C}=\mathrm{S}]$.

$\left(\mathbf{S}_{2} \mathbf{C N}^{\mathrm{i}} \mathbf{B u}_{2}\right)_{2}(3) .{ }^{22}{ }^{\mathrm{i}} \mathrm{Bu}_{2} \mathrm{NH}(2.62 \mathrm{~mL}, 15 \mathrm{mmol})$ was added to $\mathrm{NaOH}(0.60 \mathrm{~g}, 15 \mathrm{mmol})$ in water $(50 \mathrm{~mL})$. To this mixture $\mathrm{CS}_{2}$ $(0.90 \mathrm{~mL}, 15 \mathrm{mmol})$ was added dropwise over $10 \mathrm{~min}$ and the mixture stirred for $1 \mathrm{~h}$. An aqueous solution $(20 \mathrm{~mL})$ of $\mathrm{K}_{3}\left[\mathrm{Fe}(\mathrm{CN})_{6}\right](4.94 \mathrm{~g}, 15 \mathrm{mmol})$ was added dropwise over $10 \mathrm{~min}$ and stirred vigorously for $2 \mathrm{~h}$. The solution was filtered using a Büchner funnel, washed with water $(1 \times 20 \mathrm{~mL})$ and dried. The resulting beige solid was crushed to a powder using a mortar and pestle, washed with water $(3 \times 30 \mathrm{~mL})$ and dried to produce a white powder. Yield $2.79 \mathrm{~g}, 91 \% .{ }^{1} \mathrm{H}$ NMR $\delta / \mathrm{ppm}$ $\left(\mathrm{CDCl}_{3}\right): 0.93\left(\mathrm{~d}, J=6.3 \mathrm{~Hz}, 12 \mathrm{H}, \mathrm{CH}_{3}\right), 1.04(\mathrm{~d}, J=6.3 \mathrm{~Hz}, 12 \mathrm{H}$, $\left.\mathrm{CH}_{3}\right), 2.49(\mathrm{~m}, 4 \mathrm{H}, \mathrm{CH}), 3.84\left(\mathrm{~m}, 8 \mathrm{H}, \mathrm{CH}_{2}\right) \cdot{ }^{13} \mathrm{C}\left\{{ }^{1} \mathrm{H}\right\} \mathrm{NMR} \delta / \mathrm{ppm}$ $\left(\mathrm{CDCl}_{3}\right): 20.3\left(\mathrm{CH}_{3}\right), 20.5\left(\mathrm{CH}_{3}\right), 26.1(\mathrm{CH}), 28.7(\mathrm{CH}), 61.8\left(\mathrm{CH}_{2}\right)$, $65.5\left(\mathrm{CH}_{2}\right), 194.3\left(\mathrm{CS}_{2}\right)$. Anal. Calc. for $\mathrm{C}_{18} \mathrm{H}_{36} \mathrm{~N}_{2} \mathrm{~S}_{4}: \mathrm{C}, 52.89 ; \mathrm{H}$, 8.88; N, 6.85. Found: C, 52.73; H, 9.07; N, 6.90. MS: $m / z 408\left[\mathrm{M}^{+}\right]$, $204\left[\mathrm{M}^{+}-\left(\mathrm{S}_{2} \mathrm{CN}^{\mathrm{I}} \mathrm{Bu}_{2}\right)\right], 172\left[\mathrm{M}^{+}-\left(\mathrm{SCN}^{\mathrm{I}} \mathrm{Bu}_{2}\right)\right]$. 
$\left[\mathbf{C u}\left(\mathbf{S}_{2} \mathbf{C N}^{\mathrm{i}} \mathbf{B u}_{2}\right)_{2}\right](4) \cdot{ }^{39}$ A solution of $\mathrm{CuCl}_{2}(0.67 \mathrm{~g}, 5 \mathrm{mmol})$ in $\mathrm{MeOH}(50 \mathrm{~mL})$ was added dropwise over $5 \mathrm{~min}$, whereupon a black precipitate formed. This mixture was vigorously stirred for $4 \mathrm{~h}$, filtered, and then washed and dried, yielding a black powder, $2.36 \mathrm{~g}, 75 \%$. Anal. Calc. for $\mathrm{C}_{18} \mathrm{H}_{36} \mathrm{~N}_{2} \mathrm{~S}_{4} \mathrm{Cu}: \mathrm{C}, 45.78 ; \mathrm{H}$, 7.68; N, 5.93. Found: C, 45.59; H, 7.71; N, 6.20. MS: $m / z 471\left[\mathrm{M}^{+}\right]$, $172\left[\mathrm{SCN}^{\mathrm{i}} \mathrm{Bu}_{2}\right]$.

$\left[\mathbf{Z n}\left(\mathbf{S}_{2} \mathbf{C N}^{\mathrm{i} B \mathbf{B u}_{2}}\right)_{2}\right](5){ }^{40}$ A solution of $\mathrm{ZnSO}_{4} \cdot 7 \mathrm{H}_{2} \mathrm{O}(1.44 \mathrm{~g}, 5.0$ $\mathrm{mmol})$ in water $(50 \mathrm{ml})$ was added dropwise over $5 \mathrm{~min}$, whereupon a white precipitate formed. This mixture was vigorously stirred for $4 \mathrm{~h}$, filtered, and then washed and dried, yielding an off-white powder, $2.09 \mathrm{~g}, 88 \%$. Anal. Calc. for $\mathrm{C}_{18} \mathrm{H}_{36} \mathrm{~N}_{2} \mathrm{~S}_{4} \mathrm{Zn}$ : C, $45.60 ; \mathrm{H}, 7.65 ; \mathrm{N}, 5.91$. Found: C, 46.61; H, 7.97; N, 5.59. ${ }^{1} \mathrm{H}$ NMR $\delta / \mathrm{ppm}\left(\mathrm{CDCl}_{3}\right): 0.97(\mathrm{~d}, J=6.6 \mathrm{~Hz}, 24 \mathrm{H}$, $\left.\mathrm{CH}_{3}\right), 2.39(\mathrm{~m}, J=6.8 \mathrm{~Hz}, 4 \mathrm{H}, \mathrm{CH}), 3.70\left(\mathrm{~d}, J=7.5 \mathrm{~Hz}, 8 \mathrm{H}, \mathrm{CH}_{2}\right)$. ${ }^{13} \mathrm{C}\left\{{ }^{1} \mathrm{H}\right\}$ NMR $\delta / \mathrm{ppm}\left(\mathrm{CDCl}_{3}\right): 20.3\left(\mathrm{CH}_{3}\right), 27.1(\mathrm{CH}), 62.2\left(\mathrm{CH}_{2}\right)$, $204.5\left(C_{2}\right)$. MS: $m / z 472\left[\mathrm{M}^{+}\right], 268\left[\mathrm{M}^{+}-\mathrm{S}_{2} \mathrm{CN}^{\mathrm{i}} \mathrm{Bu}_{2}\right], 383$ $\left[\mathrm{ZnS}\left(\mathrm{SCN}^{\mathrm{i}} \mathrm{Bu}_{2}\right)_{2}-{ }^{\mathrm{i}} \mathrm{Bu}\right]$.

$\left[\mathbf{I n}\left(\mathbf{S}_{2} \mathbf{C N}^{\mathrm{i}} \mathbf{B u}_{2}\right)_{3}\right](\mathbf{6}) .^{41}$ A solution of $\operatorname{InCl}_{3}(1.11 \mathrm{~g}, 5 \mathrm{mmol})$ in water $(50 \mathrm{ml})$ was added dropwise over $5 \mathrm{~min}$, whereupon a white precipitate formed. This mixture was vigorously stirred for $4 \mathrm{~h}$, filtered, and then washed and dried, yielding a white powder. Large colourless crystals were obtained by slow evaporation from $\mathrm{CH}_{2} \mathrm{Cl}_{2}$. Yield $3.28 \mathrm{~g}, 90 \%$. Anal. Calc. for $\mathrm{C}_{27} \mathrm{H}_{54} \mathrm{~N}_{3} \mathrm{~S}_{6}$ In: C, 44.55; H, 7.48; N, 5.77. Found: C, 44.59; $\mathrm{H}$, 7.53; N, 5.54. ${ }^{1} \mathrm{H}$ NMR $\delta / \mathrm{ppm}\left(\mathrm{CDCl}_{3}\right): 0.95(\mathrm{~d}, J=6.6 \mathrm{~Hz}, 24 \mathrm{H}$, $\left.\mathrm{CH}_{3}\right), 2.41(\mathrm{~m}, J=6.8 \mathrm{~Hz}, 4 \mathrm{H}, \mathrm{CH}), 3.63\left(\mathrm{~d}, J=7.5 \mathrm{~Hz}, 8 \mathrm{H}, \mathrm{CH}_{2}\right)$. ${ }^{13} \mathrm{C}\left\{{ }^{1} \mathrm{H}\right\}$ NMR $\delta / \mathrm{ppm}\left(\mathrm{CDCl}_{3}\right): 20.5\left(\mathrm{CH}_{3}\right), 27.1(\mathrm{CH}), 64.0\left(\mathrm{CH}_{2}\right)$, 203.6 $\left(\mathrm{CS}_{2}\right)$. MS: $m / z 670\left[\mathrm{M}^{+}-{ }^{\mathrm{i}} \mathrm{Bu}\right], 523\left[\mathrm{M}^{+}-\mathrm{S}_{2} \mathrm{CN}^{\mathrm{i}} \mathrm{Bu}_{2}\right], 467$ $\left[\mathrm{In}\left(\mathrm{S}_{2} \mathrm{CN}^{\mathrm{i}} \mathrm{Bu}_{2}\right)_{2}-{ }^{\mathrm{i}} \mathrm{Bu}\right]$.

$\left.\left[\mathrm{Co}\left(\mathrm{S}_{2} \mathrm{CN}^{\mathrm{i} B \mathrm{Bu}_{2}}\right)_{3}\right](7)\right)^{42}$ A solution of $\mathrm{CoCl}_{2} \cdot 6 \mathrm{H}_{2} \mathrm{O}(1.00 \mathrm{~g}, 4.20$ $\mathrm{mmol})$ in water $(100 \mathrm{ml})$ was added dropwise over $5 \mathrm{~min}$, whereupon a dark green precipitate formed. This mixture was vigorously stirred for $2 \mathrm{~h}$, filtered, washed with water $(3 \times 30$ $\mathrm{mL}$ ) and evaporated to dryness. The resulting green powder was dissolved in $100 \mathrm{~mL}$ of $\mathrm{CH}_{2} \mathrm{Cl}_{2}$ and stirred with magnesium sulphate for $30 \mathrm{~min}$, after which the mixture was filtered and the filtrate dried in vacuo. Yield $1.83 \mathrm{~g}, 65 \%$. Anal. Calc. for $\mathrm{C}_{27} \mathrm{H}_{54} \mathrm{~N}_{3} \mathrm{~S}_{6}$ Co: $\mathrm{C}, 48.25 ; \mathrm{H}, 8.10$; N, 6.25. Found: C, 48.17; H, 8.16; N, 6.46. MS: $m / z 671\left[\mathrm{M}^{+}\right], 467\left[\mathrm{M}^{+}-\mathrm{S}_{2} \mathrm{CN}^{\mathrm{i}} \mathrm{Bu}_{2}\right]$.

\section{Decomposition studies}

In a typical synthesis the dithiocarbamate complexes $(2.5 \mathrm{mM})$ were added to oleylamine $(20 \mathrm{~mL})$ in a three-neck round bottom flask attached to a water condenser and evacuated and refilled with nitrogen repeatedly for $c a .15$ minutes. The solution was heated to $230^{\circ} \mathrm{C}$ for $1 \mathrm{~h}$. The mixture was slowly cooled to room temperature, whereupon methanol $(80 \mathrm{~mL})$ was added with stirring. The mixture was centrifuged and the solution decanted leaving behind the resultant nanoparticles. This procedure was repeated three times and then the material was dried under vacuum.

\section{Conflicts of interest}

There are no conflicts of interest to declare.

\section{Acknowledgements}

We thank the EPSRC for funding; PhD studentship to AR and postdoctoral fellowship to $\mathrm{NH}$.

\section{References}

1 See for example; (a) A. K Gupta and M. Gupta, Biomaterials, 2005, 26, 3995; (b) A.-H. Lu, E. L. Salabas and F. Schueth, Angew. Chem., Int. Ed., 2007, 46, 1222; (c) T. Trinade, P. O'Brien and N. L. Pickett, Chem. Mater., 2001, 13, 3843; (d) T. Hyeon, Chem. Commun., 2003, 927; (e) A. L. Rogach, D. V. Talapin, E. V. Shevchenko, A. Kornowski, M. Haase and H. Weller, Adv. Funct. Mater., 2002, 12, 653; (f) M. A. Malik, M. Afzaal and P. O'Brien, Chem. Rev., 2010, 110, 4417.

2 W. Martin and M. J. Russell, Philos. Trans. R. Soc., B, 2003, 358, 59.

3 M. J. Russell and A. J. Hall, J. Geol. Soc., 1997, 154, 377.

4 M. J. Russell, R. M. Daniel, A. J. Hall and J. A. Sherringham, J. Mol. Evol., 1994, 39, 231.

5 M. J. Russell and W. Martin, Trends Biochem. Sci., 2004, 29, 358.

6 G. Wachtershauser, Chem. Biodiversity, 2007, 4, 584.

7 N. Lane and W. Martin, Cell, 2012, 151, 1406.

8 U. P. Apfel and W. Weigand, Angew. Chem., Int. Ed., 2011, 50, 4262.

9 A. Roldan, N. Hollingsworth, A. Roffey, H.-U. Islam, J. B. M. Goodall, C. R. A. Catlow, J. A. Darr, W. Bras, G. Sankar, K. B. Holt, G. Hogarth and N. H. de Leeuw, Chem. Commun., 2015, 51, 7501.

10 A. Yamaguchi, M. Yamamoto, K. Takai, T. Ishii, K. Hashimoto and R. Nakamura, Electrochim. Acta, 2014, $141,311$.

11 M. G. Vladimirov, Y. F. Ryzhkov, V. A. Alekseev, V. A. Bogdanovskaya, V. A. Otroshchenko and M. S. Kritsky, Orig. Life Evol. Biospheres, 2004, 34, 347.

12 A. Roffey, N. Hollingsworth, H.-U. Islam, W. Bras, G. Sankar, N. De Leeuw and G. Hogarth, Nanoscale Adv., submitted.

13 G. Hogarth, Prog. Inorg. Chem., 2005, 53, 71.

14 M. Afzaal, M. A. Malik and P. O'Brien, J. Mater. Chem., 2010, 20, 4031.

15 (a) A. Saunders, A. Vecht and G. Tyrell, Chem. Abs., 1988, 108, 66226h; (b) A. Birri, B. Harvey, G. Hogarth, E. Subasi and F. Ugar, J. Organomet. Chem., 2007, 692, 2448; (c) R. Nomura, K. Miyawaki, T. Toyosaki and H. Matsuda, Chem. Vap. Deposition, 1996, 2, 174; (d) M. Kemmler, M. Lazell, P. O'Brien, D. J. Otway, J.-H. Park and J. R. Walsh, J. Mater. Sci.: Mater. Electron., 2002, 13, 531; (e) M. J. Almond, H. Redman and D. A. Rice, J. Mater. Chem., 2000, 10, 2842; $(f)$ F. Srouji, M. Afzaal, J. Waters and P. O'Brien, Chem. Vap. Deposition, 2005, 11, 91; $(g)$ P. O'Brien, D. J. Otway and J.-H. Park, Mater. Res. Soc. Symp. Proc., 2000, 606, 133; (h) J. M. Soon, L. Y. Goh, K. P. Loh, Y. L. Foo, L. Ming and J. Ding, Appl. Phys. Lett., 2007, 91, 084105; (i) O. C. Monteiro, H. I. S. Nogueira and 
T. Trindade, Chem. Mater., 2001, 13, 2103; (j) P. O'Brien, D. J. Otway and J. R. Walsh, Thin Solid Films, 1998, 315, 57. 16 (a) B. L. Druz, Y. N. Eutukhov and M. Y. Rakhlin, Organomet. Chem., 1988, 1, 357; (b) P. O'Brien, J. R. Walsh, I. M. Watson, M. Motevalli and L. Henrikson, J. Chem. Soc., Dalton Trans., 1996, 2491; (c) R. D. Pike, H. Cui, R. Kershaw, K. Dwight, A. Wold, T. N. Blanton, A. A. Wernberg and H. J. Gysling, Thin Solid Films, 1993, 224, 221; (d) D. M. Frifo, O. F. Z. Khan and P. O'Brien, J. Cryst. Growth, 1989, 96, 989; (e) J. Wang, J. R. Hyde, J. W. Wilson, K. Mallik, P. J. Sazio, P. O'Brien, M. A. Malik, M. Afzaal, C. Q. Nguyen, M. W. George, S. M. Howdle and D. C. Smith, Adv. Mater., 2009, 21, 4115; (f) Y. M. Rumyantsev, N. I. Fainer, M. L. Kosinova, B. M. Ayupov and N. P. Sysoeva, J. Phys. IV, 1999, 9, 777; $(g)$ N. I. Fainer, M. L. Kosinova, Y. M. Rumyantsev, E. G. Salman and F. A. Kuznetsov, Thin Solid Films, 1996, 280, 16; (h) N. I. Fainer, Y. M. Rumyantsev, M. L. Kosinova and F. A. Kuznetsov, Electrochemical Society, 1997, 25-97, 1437; (i) D. Zeng, M. J. Hamden-Smith, T. M. Alam and A. L. Rheingold, Polyhedron, 1994, 13, 2715; (j) B. Ludolph, M. A. Malik, P. O'Brien and N. Revaprasadu, Chem. Commun., 1998, 1849; (k) N. Revaprasadu, M. A. Malik, J. Carstens and P. O. Brien, J. Mater. Chem., 1999, 9, 2885.

17 (a) M. A. Malik, P. O'Brien and N. Revaprasadu, Chem. Mater., 2002, 14, 2004; (b) M. A. Malik, N. Revaprasadu and P. O'Brien, Chem. Mater., 2001, 13, 913; (c) M. Lazell and P. O'Brien, J. Chem. Soc., Chem. Commun., 1999, 2041; (d) P. Sreekumari Nair, N. Revaprasadu, T. Radbakrishnan and G. A. Kolawole, J. Mater. Chem., 2001, 11, 1555; (e) T. Trindade, P. O'Brien and X.-M. Zhang, Chem. Mater., 1997, 9, 523; $(f)$ D. C. Onwudiwe and P. A. Ajibade, Int. J. Mol. Sci., 2011, 12, 5538; $(g)$ D. C. Onwudiwe and P. A. Ajibade, Mater. Lett., 2011, 65, 3258; (h) P. A. Ajibade, D. C. Onwudiwe and M. J. Moloto, Polyhedron, 2011, 30, 246; (i) V. S. R. Pullabhotla, S. M. Rajasekhar and N. Revaprasadu, J. Nanosci. Nanotechnol., 2011, 11, 1201; (j) R. Marx Nirmal, K. Pandian and K. Sivakumar, Appl. Surf. Sci., 2011, 257, 2745; (k) L. D. Nyamen, P. R. S. Viswanadha, A. A. Nejo, P. Ndifon and N. Revaprasadu, New J. Chem., 2011, 35, 1133; (l) E. Y. M. Lee, N. H. Tran and R. N. Lamb, Appl. Surf. Sci., 2005, 241, 493; $(m)$ M. Motevalli, P. O'Brien, J. R. Walsh and I. M. Watson, Polyhedron, 1996, 15, 2801; (n) P. O'Brien, J. R. Walsh, I. M. Watson, L. Hart and S. R. P. Silva, J. Cryst. Growth, 1996, 167, 133; (o) L. D. Nyamen, A. A. Nejo, V. S. R. Pullabhotla, P. T. Ndifon, M. A. Malik, J. Akhtar, P. O'Brien and N. Revaprasadu, Polyhedron, 2014, 67, 129; (p) L. D. Nyamen, N. Revaprasadu, R. V. S. R. Pullabhotla, A. A. Nejo, P. T. Ndifon, M. A. Malik and P. O'Brien, Polyhedron, 2013, 56, 62; (q) A. L. Abdelhady, M. Afzaal, M. A. Malik and P. O'Brien, J. Mater. Chem., 2011, 21, 18768.

18 (a) W. Han and M. Y. Gao, Cryst. Growth Des., 2008, 8, 1023; (b) Y. Zhang, Y. Du and Q. Wang, CrystEngComm, 2010, 12, 3658; (c) M. Akhtar, J. Akhter, M. A. Malik, P. O'Brien, F. Tuna, J. Raftery and M. Helliwell, J. Mater. Chem., 2011,
21, 9737; (d) M. Akhtar, A. L. Abdelhady, M. A. Malik and P. O'Brien, J. Cryst. Growth, 2012, 346, 106.

19 (a) A. Adeogun, M. Afzaal and P. O'Brien, Chem. Vap. Deposition, 2006, 12, 597; (b) O. C. Monteiro and T. Trindade, Mater. Res. Bull., 2004, 39, 357; (c) Y. Lou, A. C. S. Samia, J. Cowen, K. Banger, X. Chen, H. Lee and C. Burda, Phys. Chem. Chem. Phys., 2003, 5, 1091; (d) Z. Liu, D. Xu, J. Liang, J. Shen, S. Zhang and Y. Qian, J. Phys. Chem. B, 2005, 109, 10699; (e) J. C. Bear, N. Hollingsworth, P. D. McNaughter, A. G. Mayes, M. B. Ward, T. Nann, G. Hogarth and I. P. Parkin, Angew. Chem., Int. Ed., 2014, 53, 1598; (f) K. Ramasamy, V. L. Kuznetsov, K. Gopal, M. A. Malik, J. Raftery, P. P. Edwards and P. O'Brien, Chem. Mater., 2013, 25, 266; (g) K. Ramasamy, M. A. Malik and P. O'Brien, Chem. Commun., 2012, 48, 5703; (h) M. Afzaal, C. L. Rosenberg, M. A. Malik, A. J. P. White and P. O'Brien, New J. Chem., 2011, 35, 2773; (i) K. Ramasamy, M. A. Malik and P. O'Brien, Chem. Sci., 2011, 2, 1170.

20 (a) P. O'Brien and J. Waters, Chem. Vap. Deposition, 2006, 12, 620; (b) H. Cui, R. D. Pike, R. Kershaw, K. Dwight and A. Wold, J. Solid State Chem., 1992, 101, 115; (c) P. O'Brien, J.-H. Park and J. Waters, Thin Solid Films, 2003, 431, 502; (d) G. H. Singhal, R. I. Botto, L. D. Brown and K. S. Colle, J. Solid State Chem., 1994, 109, 166; (e) R. Nomura and N. Nakai, Trans. Mater. Res. Soc. Jpn., 2003, 28, 1287; $(f)$ X. Chen, Z. Wang, X. Wang, J. Wan, J. Liu and Y. Qian, Chem. Lett., 2004, 33, 1294; $(g)$ R. Chauhan, M. Trivedi, J. Singh, K. C. Molloy, G. Kociok-Köhn, U. P. Mulik, D. P. Amalnerkar and A. Kumar, Inorg. Chim. Acta, 2014, 415, 69.

21 N. Hollingsworth, A. Roffey, H.-U. Islam, M. Mercy, A. Roldan, W. Bras, M. Wolthers, C. R. A. Catlow, G. Sankar, G. Hogarth and N. H. de Leeuw, Chem. Mater., 2014, 26, 6281.

22 A. Roffey, N. Hollingsworth, H.-U. Islam, M. Mercy, C. R. A. Catlow, G. Sankar, N. H. de Leeuw and G. Hogarth, Nanoscale, 2016, 8, 11067.

23 A. Wold and K. Dwight, Solid State Chemistry: Synthesis, Structure, and Properties of Selected Oxides and Sulfides, Chapman and Hall, 1993.

24 (a) D. J. Vaughan and J. R. Craig, Am. Mineral., 1947, 70, 1036; (b) G. Kullerud, Can. Mineral., 1963, 7, 353; (c) V. Raghavan, J. Phase Equilib. Diffus., 2004, 25, 373; (d) M. R. Thornber, J. Appl. Electrochem., 1983, 13, 253; (e) P. Bayliss, Am. Mineral., 1989, 74, 1168.

25 I. Bezverkhyy, P. Afanasiev and M. Danot, J. Phys. Chem. B, 2004, 108, 7709.

26 R. Pastorek, P. Štarha, T. Peterek and Z. Trávníček, Polyhedron, 2011, 30, 2795.

27 M. E. Fleet, Rev. Mineral. Geochem., 2006, 61, 365.

28 (a) A. M. Wiltrout, N. J. Freymeyer, T. Machani, D. P. Rossi and K. E. Plass, J. Mater. Chem., 2011, 21, 19286; (b) V. S. Gurin, Colloids Surf., A, 1998, 142, 35; (c) A. M. Malyarevich, K. V Yumashev, N. N. Posnov, V. P. Mikhailov and V. S. Gurin, Appl. Phys. B, 2000, 70, 111; (d) A. M. Malvarevich, K. V Yumashev, N. N. Posnov, 
V. P. Mikhailov and V. S. Gurin, J. Appl. Spectrosc., 2000, 67, 359; (e) E. A. Nevar, N. A. Savastenko, V. Bruser, D. A. Lopatik, F. May, A. V Butsen, N. V Tarasenko and V. S. Burakov, J. Appl. Spectrosc., 2010, 77, 136; (f) K. Aup-Ngoen, T. Thongtem, S. Thongtem and A. Phuruangrat, Mater. Lett., 2013, 101, 9.

29 Y.-H. A. Wang, N. Bao and A. Gupta, Solid State Sci., 2010, 12, 387.

30 D. Liang, R. Ma, S. Jiao, G. Pang and S. Feng, Nanoscale, 2012, 4, 6265.

31 (a) V. Blagojević, G. A. Gledhill, A. Hamilton, S. B. Upadhyay, P. M. Nikolić, M. B. Pavlović and D. I. Raković, Infrared Phys., 1991, 31, 387; (b) A. A. Vaipolin, Y. A. Nikolaev, I. K. Polushina, V. Y. Rud', Y. V. Rud', E. I. Terukov and N. Fernelius, Semiconductors, 2003, 37, 681.

32 Q. J. Feng, D. Z. Shen, J. Y. Zhang, Y. M. Lu, Y. C. Liu and X. W. Fan, Mater. Chem. Phys., 2006, 96, 158.
33 D. Disale and S. S. Garje, J. Organomet. Chem., 2011, 696, 3328.

34 Y. Li, C. Cao and Z. Chen, Mater. Lett., 2011, 65, 2432.

35 Y. Shi, Y. Wang and L. Wu, J. Phys. Chem. C, 2013, 117, 20054.

36 H. Chen, J. Jiang, L. Zhang, H. Wan, T. Qi and D. Xia, Nanoscale, 2013, 5, 8879.

37 W. Du, Z. Zhu, Y. Wang, J. Liu, W. Yang, X. Qian and H. Pang, RSC Adv., 2014, 4, 6998.

38 A. H. White, R. Roper, E. Kokot, H. Waterman and R. L. Martin, Aust. J. Chem., 1964, 17, 294.

39 S. C. Ngo, K. K. Banger, M. J. DelaRosa, P. J. Toscano and J. T. Welch, Polyhedron, 2003, 22, 1575.

40 A. M. Bond and A. F. Hollenkamp, Inorg. Chem., 1990, 29, 284.

41 M. L. Riekkola and O. Makitie, J. Therm. Anal., 1982, 25, 89. 42 J. E. J. Schmitz and J. G. M. Van der Linden, Inorg. Chem., 1984, 23, 3298. 